\title{
Study on American University Education
}

\author{
Yan Zhu \\ College of Environment and Chemical Engineering \\ Xi'an Polytechnic University \\ Xi'an 710048, China \\ zhuyan_1963@126.com
}

\author{
Guang Yuan \\ Xi'an Polytechnic University \\ Xi'an 710048, China \\ 939358037@qq.com
}

\author{
Shuai Yuan \\ Department of Material Science and Engineering \\ Zhejiang University \\ Hangzhou 310027, China \\ shuaiyuan0821@zju.edu.cn
}

\begin{abstract}
The goal of visiting University of Minnesota is observing and studying U.S. university education and finding similarities and differences both Chinese education and American education to estimate university education of $\mathrm{Xi}$ 'an Polytechnic University. Based on visiting the University of Minnesota, A lot of similarities and differences both Chinese education and American education have been found. Through the analysis of these similarities and differences, the advantages and shortcomings of both Chinese education and American education can be found. The essence of American' $s$ university education should be learnt in order to serve China education. The advantages of China socialist characteristics university education should be developed. After this interview, it can be sure that the top-level design of Applied Chemistry of $\mathrm{Xi}^{\prime}$ an Polytechnic University is right and the education reform practiced over the years is correct. All things we do conform to the laws of world educational development. The education of Applied Chemistry Specialty of Xi'an Polytechnic University has entered the orbit of world education.
\end{abstract}

Keywords-China university education;American university education;similarities and differences;characteristics

\section{INTRODUCTION}

Xi'an Polytechnic University integrating knowledge application, learning and research into higher education organized by University of Minnesota China center Mingda Institute for leadship training was held at the University of Minnesota in the United States. The training program carried out for a period of 14 days. We departed from Xi'an Polytechnic University in February 13, 2016 and returned back to Xi'an Polytechnic University in February 27, 2016. It took 4 days on the road, from Xi'an, Shanghai, and San Francisco to Minnesota, then back from Minnesota, Chicago, and Shanghai to Xi'an. The learning schedule every day is very full, which began on February 15th.and graduated on February 25th.We must have 4-6 class every day on average. The main content includes having lectures, visiting every school and other university, talking with Chinese international students, touring Twin Cities scenic spots and shopping. The goal of visiting University of Minnesota is observing and studying U.S. university education and finding similarities and differences both Chinese education and American education to estimate university education of Xi'an Polytechnic University.

\section{INTRODUCTION OF UNIVERSITY OF MINNESOTA}

University of Minnesota was built in 1851. There are 4168 teachers, 17 school, more than 370 speciality, more than 40 thousand and 800 undergraduate students, more than 16 thousand and 700 graduate students now. More than 12 thousand China students and scholars studied in the University of Minnesota since 1914.There are more than 2700 Chinese students and scholars are studying and working at present. The universities have $\$ 3600$ million of operating budget, $\$ 200$ million of all donations and $\$ 850$ million research funding. University of Minnesota have 5 campuses, namely Twin Cities Campus - Minneapolis and St Paul campus, Duluth campus, Morris campus, Rochester campus and Crookston campus. The Minneapolis campus of Twin Cities campus is larger one, which located on both sides of the Mississippi River. Here are the natural sciences and the engineering school, medical school, law school, business school, the school of public administration and the humanities. The St Paul campus of the Twin Cities campus includes the school of food and Agricultural Sciences, the school of design, the school of continuing education, and the school of veterinary medicine.

\section{TRAINING PROGRAM}

Training program began from visiting St. Anthony falls laboratory in University of Minnesota at 8.25 am on February 15th and ended after attending Professor Jason Cao lecture on how to write scientific research papers at 2 pm on February 25th. We heard a total of 21 reports which were as follows: Performance evaluation for U.S. research universities. How American universities raise and manage research funds. How UMN faculty member applies theories to patents. Introduction to office of technology commercialization and the processes used to commercialize technology. Research compliance (III): conflict of interest. IT processes in GPS alliance and our partnership with OIT. Overview of U.S. political system and its 


\section{Asunses PRESS}

financial implication for public research universities. Research compliance (IV): research misconduct and research ethics. Functions of the office of institutional research. Administrative management and decision making within U.S. universities: interaction between university, college, and departments, et al. The contents of the training course included American higher education system running, evolution of American land grant universities and public research universities, role and responsibilities of the board and the president of U.S. universities, overview of U.S. political system and its financial implications for public research universities, research misconduct and research ethics, teaching, research, and services of the faculty in U.S. universities, scientific research paper writing.

Visiting St. Thomas University, St. Catharines University, University of Minnesota, St. Anthony falls laboratory, Minnesota campus.

\section{U.S. UNIVERSITY EDUCATION}

Through learning the course, the whole process of formation, operation, enrollment, training, graduation of public universities in the United States basically understood. University education in the United States has history of more than 400 years. The operation of American universities is composed of the board, the president, the dean, the teachers and the students. The United States universities were divided into public university and private university. A lot of U.S. public universities are land grant universities, namely, the government provided free land to build a university in every state, so there is a fair education condition. Fund is provided by the state government funding and tuition. Enrollment is easy and graduation is strict. $30-70 \%$ students can get graduation certificate. Research funding can be get from government funding and ventures. The role and responsibility of the board and the president of the universities is to raise money and appointed school leaders. Dean is responsible for arranging task of teaching and scientific research. Teachers are responsible for teaching and research. Staff is responsible for logistics management. Research misconduct and research ethics is highly taken seriously. Research integrity is emphasized. All including make up the data, resort to deceit and plagiarism are research misconduct. Plagiarizing other's thoughts and ideas should be blacklisted and punished by law. The integrity of research is ensured by policy, environment and regulation in U.S. universities. Today China's higher education begins to pay more and more attention to academic ethics and integrity, but it is less strict than U.S. Some people will steal other people's work, ideas, for their own interests and small groups. They don't think it as shameful. They should also be blacklisted. The recruitment of graduate students in the United States is based on the actual needs of the tutor. The establishment of master's degree and doctor's degree is decided by the development of the university board, and does not need to report to the higher authorities for approval. This is different from our higher education.

\section{VISITING IMPRESSION}

I was impressed by St. Anthony falls laboratory in University of Minnesota which built on the Mississippi River. The lab is good example of linking theory with practice and can directly solve the practical problems of the Mississippi River through experimental research. Experimental site is large, equipment is advance and researchers including graduate students professional spirit are very strong. A lot of equipment was made by researchers themselves. Jason Cao, "How to write scientific research paper" give prominence to the key points. His paper has a strong guiding significance.

I gain a lot from this training. First, I personally heard and saw whole process of operation, recruitment, training, graduation and operation of all aspects of research of the American public university. Second, I understood policies and practices of US public university research. Third, I understand the research from similarities to differences between the United States and China. For example, University of Minnesota University has no walls, China university have. University of Minnesota ensures teaching quality by controlling graduation certificate percentage to ensure quality, China university pursue high graduation rates which is obtained through strengthening management of students. At the same time, we also experienced the customs of Minnesota. Minnesota people are honest, enthusiastic, helping others. Chinese center teachers are responsible for arranging whole treating process; they looked after our life also. After class, the shopping center arranged our delegation shopping to understand American market. We are very envious of the spacious teaching environment and advanced multi-functional teaching equipment, for example, there are blackboard on four walls and projection and amplifying equipment near each seat in the classroom. I appreciated no waste, for example, Catherine University teaching building was originally a swimming pool, then changed into the teaching building, the swimming pool is not removed, teaching building built directly in the swimming pool.

\section{Chinese University Education Reform}

At present, Chinese university education is at a critical point of how to go to future. To establish firmly the sense of reform and innovation, to join actively practice of educational innovation, to develop modern education which has Chinese characteristics and the world level should be our responsibility. General Secretary $\mathrm{Xi}$ in investigation, speech, instruction elaborated teachers important role from the angle of educational fairness, reform and innovation, moral education. He indicated that teachers are a foundation of Teaching and the source of education. The teachers take important responsibility of the healthy growth of each child and run the people's satisfaction education. He hopes the teachers firmly establish the Chinese characteristic socialist ideals and beliefs and take the lead in the implementation of socialist core values, consciously enhance responsibility of cultivating students' morality, imparting knowledge and educating people, guiding students to grow up healthy with the behavior of teachers. He hopes the teachers diligently study, broaden horizons, update knowledge, and continuously improve the quality of business skill, and strive to become the high quality teachers with 


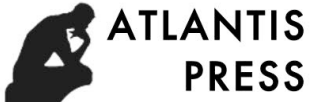

business skills and students love. The teachers firmly establish the concept of reform and innovation, actively participate education innovation practice and creatively develop the world's modern education with Chinese characteristics. [1] The core values reflects a nation's spirit and pursuit, embodies the value standard of a society to judge the right and wrong. [2] An important part of university education is to cultivate the values of the youth. The values of young people determine the future values of the whole society. The values of the youth is forming during they admit to university. it's like buttoning clothes. If the first button is wrong, the remaining buttons will be wrong. The core values of a person is formed from easy to difficult, from near too far, We must let socialist core values become the daily behavior criterion and consciously pursuing the idea. The value orientation of young people determines the value orientation of the whole society in the future while the youth is in the formation and establishment of the value orientation. It is very important to help the youth forming correct idea in this time. The concept of core values can't formed in a day. All the young people establish and cultivate the socialist core value with diligent learning, strengthening morality, clear debating, serious working, doing anything hard, getting true knowledge, strengthening moral cultivation, paying attention to moral practice, good at distinguishing between right and wrong, good at decisioning and choosing, down-to-earth doing thing, steadfasting personhood, serving the motherland and the people, combining together between theory and practice. [3] The universities must strengthen their spirit and moral construction and strive to achieve in each class, not only the dissemination of knowledge, but also to teach virtue. Every school and university must put moral education in a more important position and strengthen the school spirits and the teacher moral construction. [4] We should develop vigorously science and technology; we must know the world through science and technology progress and innovation. We should vigorously develop science and technology. We must know yourself and the world through scientific and technological progress and innovation so as to transform the society. We must grasp continuously scientific and technological knowledge and skills, so that it can serve the mankind. We should vigorously promote the development of Chinese culture through cultural exchanges and communication of mind, broadening our horizons, increasing consensus, continuously improving cultural quality, so as to let culture help people to progress. [5] Justice is not only a virtue; it is a kind of power also. To achieve justice through education reform is not only a kind of reform practice, but a reform dynamic also. China has begun to deepen the reform today. Education reform promoting fairness and justice will be a welcomed the reform practice and cyclical Reform momentum [6]. Now China is in the Great Renaissance era, an important task of modern education is how to establish a new moral concept and stand in the world with a new look and good quality. Education is the most important thing which we must do in hundred years. Teachers are the most important persons who can establish and develop education. They are the engineer of the human soul. So first of all, teachers must have excellent quality themselves, namely they must adhere the education principle of fair, morality, reform and innovation, actively put into the practice of educational innovation, cultivate students to become talents who have fair, knowing true or false, seeking truth from facts, magnanimous, sincere, kind and who can insist on moral bottom line so as to contribute to develop international level modern education which have Chinese characteristics.

At present, the central government put forward to promote the socialist core values which is becoming Chinese people behave bottom line. The socialist core value concept includes prosperity, democracy, civilization, harmony, freedom, equality, justice, rule of law, patriotism, dedication, integrity, kindness. Yuan Guiren's article "adhere to establish moral and cultivate people, strengthen the socialist core values education" [2] said the core values is carrying the spirit pursuit of our nation and country and embodies the value standard to judge the merits of our society. If everyone can adhere the socialist core values, the moral prosperity of Chinese society can come true after a number of years. In education area, fairness, morality, reform says easy and does difficulty. If we can really do this, the students we taught must have the idea of fair, morality and can become the backbone of practicing socialist core values.

Fairness, morality, reform is indeed the direction and trend of education reform. It can lay the foundation to promote the socialist core value view. The construction of teaching staff in Colleges and universities is very important, while teacher's moral construction is the most important. In the process of establishing and perfecting long-term mechanism of college teachers' moral construction, it is sure to take a clear-standard, clear orientation, distinguish between the mainstream and tributaries, firmly grasp the main line of teaching both knowledge and morality at same time, establish morality and cultivate people . Education of fairness and justice must be done and the fairness and justice of education must be embodied[7]. School and university are the second classroom where everybody grow up. Moral and academic standards are important questions for the school and university to cultivate their students. The students today are the brick, tile, and stone of building our country tomorrow. What kind of students should be trained? The General Secretary Xi's speech is summarized as cultivating students' idea and behavior criterion of justice, morality and reform and innovation. First of all, school and university must cultivate the students ability to discern good or bad. The students should be simple, honest, open-minded, kind-hearted, kindness. They can adhere correct and have courage to fight bad people and bad things. They should establish the concept of fairness and justice, doing thing should be based on the principle of seeking truth from facts, people-oriented, fair distribution, adhering the correct bottom line. They should know the things which can do and not do. They not only have the principle but also have the flexibility in work. Education reform should be based on the principle of innovation. Original innovation should be more emphasized. Academic misconduct should be resolutely put an end. The students should be nurtured and grown in correct teaching and research environment, while this environment is created by high quality teachers. So the teacher morality and ability is very important. It is desired to correct teachers' ideological belief, to enhance the ability to distinguish right and wrong. The teachers must overcome the bad habits, including confounding right and wrong, forgetting justice in order to 
profit, tametoshi figure, bullying the weak, forming cliques, forming interest circle. Teachers should have high quality and become the model for the students. In addition, each link of teaching should be based on the actual situation of the school and highlight the characteristics of the teaching in the teaching process. There should be the characteristic book, teaching methods, experiment and practice. It is necessary to construct necessary experimental and practical bases, strengthen the contact with the enterprise, and developed steady out-college practice base. When justice, morality, reform ideas take root in the minds of students, The students should become the backbone of the practice of socialist core values.[8]

\section{CONCLUSION}

This training is very helpful for us to understand U.S. university education. First of all, it can lay the foundation for our university education and education in the world. We can compare the differences between the two countries in their education. According to the actual development of our university to promote the advantages of our university, to correct the disadvantages of our university, take the road of university education with Chinese characteristics. After this interview, it can be sure that the top-level design of Applied Chemistry in our university is right and the education reform practiced over the years is correct. All things we do conform to the laws of world educational development. The education of Applied Chemistry Specialty in our universities has entered the orbit of world education.

Next step we strengthen the construction of student study attitude, we will rectificate strictly teachers' ethics at the same time. We must wipe out erroneous tendencies about what can be done for the sake of interests and double face person who smiled on the face and take a knife in his hand. The teachers' ethics will be raise to new level to set an example for students. The 13th Five-Year target of Applied Chemistry Specialty in our universities has been completed ahead. Next we will achieve new goal to let Applied Chemistry Specialty in Xi'an Polytechenic University into national advanced specialty ranks.

\section{ACKNOWLEDGMENT}

This research was financially supported by the National Science Foundation and Science and Technology Foundation of Shanxi.

\section{REFERENCES}

[1] J.P.XI,"Letter to the majority of Teachers",http://edu.youth.cn/2013/ 0910/122139.shtml,2013,9.10

[2] G.R.Yuan, "To strengthen the morality education education of socialist core values",http://www.dangjian.cn/ll/xxck/201405/t20140523_1961 468.shtml,2014,5.23

[3] J.P.XI, "Young people should consciously practice the socialist core values", http://news.xinhuanet.com/2014-05/04/c_126460590.htm 2014.5.4

[4] J.P. XI, "Let the seeds of the socialist core values in the hearts of young children to take root and sprout" ,http://tv.people.com.cn/n/2014/0530/ c141029-25088378.html,2014,5.30

[5] J.P. XI, "A speech at the United Nations Educational, scientific and Cultural Organization",http://news.youth.cn/jsxw/201403/t20140327_ 4932688.htm,2014,3.27

[6] S.H.Li, "The realization of educational equity to make up the historical debts", Guangming Daily,2014,3.11

[7] Yan Zhu,Guang Yuan, Shuai Yuan, "The reform direction of chinese university education", Destech Publications,Inc.381

[8] Guang Yuan,Yan Zhu,Shuai Yuan, "Past and present analysis of both school and university education in china", Destech Publications,Inc.50 